\title{
Contact-tracing in gonorrhoea
}

\author{
M. J. HARE*, A. MURIEL LAMB* ${ }^{\ddagger}+$ AND DOROTHY M. KING ${ }^{\star}+\ddagger$ \\ From ${ }^{\star}$ the Whitechapel Clinic, The London Hospital, and the $\dagger$ Department of Health, London Borough of Tower \\ Hamlets
}

The recent increase in the numbers of reported cases of sexually transmitted diseases has aroused public concern and prompted discussion on radio, television, and in the press. Particular interest has been shown in methods for the prevention of spread of such diseases, and in the tracing of the sexual contacts of known cases of infection. In March, 1969, a Private Members' Bill to provide for the compulsory examination of individuals thought likely to be infected was debated in Parliament and withdrawn only after assurances from the Government that a review would be made at a later date.

The aim of this communication is to report the results of contact-tracing by the non-compulsory methods at present in use.

\section{Patients}

These were 119 heterosexual men, who were treated for gonococcal urethritis between January, 1967, and January, 1968. These men were included in a study of the possible relationship between mycoplasmas and nongonococcal genital infection (Hare, Dunlop, and TaylorRobinson, 1969); it was planned that each man was to return for three examinations during the course of the 28 days immediately following treatment. Deep-sea mariners for whom follow-up was impossible were excluded: however, such men accounted for less than 5 per cent. of the men presenting because of gonorrhoea. No selection was made on the basis of race. The group comprised 45 men born in the United Kingdom, 43 from the Caribbean, twelve from Pakistan, nine from Malta, four from Eire, and two each from India, Western Europe, and West Africa.

At the first visit details of all recent sexual exposures were noted by the clinician, and the importance of contact-tracing was stressed to the patient. Whenever possible he was persuaded to take 'contact-slips' to pass on. Next he was interviewed by the Social Worker to elicit full details of known partners, and any information possible about casual contacts. Further interviews took place at later visits if the women remained unaccounted for.

Received for publication January 23, 1970. $\ddagger$ Social workers

\section{Results}

All relevant sexual contacts mentioned, whether identifiable or not, are included; these are divided in two groups (Dunlop, 1963).

(a) Reservoir The woman from whom it was thought that the patient had contracted gonorrhoea.

(b) Secondary Any women whom the patient might subsequently have infected.

Although in most cases this division was easy, in some the wrong differentiation may have been made. Contacts were recorded as attending only if they were seen at the Whitechapel Clinic, or if properly authenticated evidence of attendance at another clinic was obtained. This would entail a contact-slip returned from that clinic, giving the diagnosis and case number, or a direct message from the clinic confirming the contact's attendance. Contacts whose attendance elsewhere was alleged but not proven, and any who were supposed to have been treated by general practitioners, are not included in these figures.

The results are summarized in Table I. The 119 men gave details of varying completeness of 145 recent sexual contacts. Of these women, 117 were judged to be the sources of infection (two of the 119 men persisted in complete denial of sexual contact). The remaining 28 women were thought to be at risk of having acquired gonorrhoea from

TABLE I Attendances of contacts alleged by 119 men

\begin{tabular}{|c|c|c|c|}
\hline Contacts & Reservoir & Secondary & Total \\
\hline $\begin{array}{l}\text { Number of contacts } \\
\text { alleged }\end{array}$ & 117 & 28 & 145 \\
\hline $\begin{array}{c}\text { Number attending: } \\
\text { Whitechapel } \\
\text { Elsewhere }\end{array}$ & $\begin{array}{r}39 \\
8\end{array}$ & $\begin{array}{r}21 \\
2\end{array}$ & $\begin{array}{l}60 \\
10\end{array}$ \\
\hline Total & 47 & 23 & 70 \\
\hline $\begin{array}{l}\text { Percentage attending } \\
\text { Percentage of those attend- } \\
\text { ing who were found to be } \\
\text { infected }\end{array}$ & 40 & 100 & 48 \\
\hline
\end{tabular}


these men as secondary contacts. Of the 145 women, seventy attended for examination: 47 reservoir contacts and 23 secondary contacts. Therefore 40 per cent. of those indicated as reservoir contacts attended; if the partners who were the sources of infection of the two men who denied exposure to risk are included, this figure drops to 39 per cent. Gonococcal infection was found in 41 (87 per cent.) of the source contacts and in all of the secondary contacts.

Willcox, Jefferiss, and Naughten (1966) noted particular difficulties in performing this work among West Indian immigrants, and similar difficulties were encountered in the present study. The results obtained with West Indians compared with those obtained with men born in the United Kingdom are shown in Table II. Of the 43 West Indian men in this study, 41 admitted to sexual intercourse, and ten of their reservoir contacts attended (23 per cent. of an assumed 43). All of the 45 British-born men in the study indicated a presumptive source, and 24 (53 per cent.) of these attended. This difference did not extend to secondary contacts: thirteen of the fourteen women mentioned by West Indians attended, compared with seven of the ten mentioned by Britishborn men. No other racial groups are large enough to permit a similar comparison.

TABLE II Comparison of attendances of sexual contacts of West Indian immigrants and men born in the United Kingdom

\begin{tabular}{|c|c|c|c|c|c|}
\hline \multicolumn{2}{|c|}{ Place of birth of patient } & \multicolumn{2}{|c|}{$\begin{array}{l}\text { West Indies } \\
(43)\end{array}$} & \multicolumn{2}{|c|}{$\begin{array}{l}\text { United } \\
\text { Kingdom (45) }\end{array}$} \\
\hline Type of contact & & $\begin{array}{l}\text { Reser- } \\
\text { voir }\end{array}$ & $\begin{array}{l}\text { Secon- } \\
\text { dary }\end{array}$ & $\begin{array}{l}\text { Reser- } \\
\text { voir }\end{array}$ & $\begin{array}{l}\text { Secon- } \\
\text { dary }\end{array}$ \\
\hline \multirow[t]{2}{*}{ Number of contacts } & Alleged & 41 & 14 & 45 & 10 \\
\hline & Attending & 10 & 13 & 24 & 7 \\
\hline
\end{tabular}

\section{Discussion}

To obtain the patient's full co-operation it is important to encourage understanding of the difficulties involved in this work. Most men think that the women involved will spontaneously seek advice because of symptoms, and many men blame their contacts for having knowingly infected them. Similarly, many men are inclined to wait for their regular consorts to develop symptoms before warning them of possible infection. Dunlop (1963) reported that, of 100 women attending a clinic and found to be infected with gonorrhoea, only 22 had come because of symptoms; 69 had come because their consorts had developed a urethral discharge, although direct questioning elicited that some of them had symptoms. If infected men can be convinced of the asymptomatic nature of the disease in women, much better cooperation is obtained.

When the patient's recollections about his partners are vague, for example in episodes involving prostitutes or casual contacts, the local knowledge of the social workers may enable them to recognize a woman who has been infected before, or for whom they are searching in connection with another case. In such situations, or when the man is unable or unwilling to approach the woman again himself, the social worker will do this; in very difficult cases the woman may be called for at her home and brought to the clinic by car. Information about contacts in other districts is passed in strict confidence to a social worker at the appropriate clinic.

Comparison of the results of the present study with those of Dunlop (1963), who used the contact-slip method alone, shows considerable improvement in tracing the sources of infection. In a study conducted in a similar area of London, only six of 100 partners who were alleged to be sources of infection were known to have been examined. This compares with 47 of an assumed 119 in the present study. However, of 22 secondary contacts mentioned, eighteen attended: a proportion similar to that found in the present study. Thus it is apparent that, although the contactslip method is as effective for the secondary group (usually wives, fiancées, or regular girl-friends), more intensive methods are needed for the promiscuous group forming the reservoir of infection.

\section{Summary}

An intensified method of contact-tracing in cases of men presenting with gonorrhoea is described.

119 men interviewed first by the clinician and then by the social worker, if necessary several times, nominated 145 recent sexual partners. Of the 117 alleged sources of infection 40 per cent., and of the 28 admitted secondary contacts 82 per cent., were located and examined. The overall successful tracing rate was 48 per cent. The yield of 'reservoir' contacts from West Indian patients was smaller than that from a comparable number of men born in the United Kingdom. Results by this method are compared with those achieved by using contact-slips only, in a similar study reported in 1963. This present method was conspicuously more successful in tracing 'reservoir' contacts.

We should like to thank Dr. E. M. C. Dunlop, Senior Physician at the Whitechapel Clinic of The London Hospital, for his help and criticism in the preparation of this paper. One of us (M.J.H.) is at present holder of the B.M.A. Insole Research Award. 


\section{References}

Dunlop, E. M. C. (1963) Brit. F. vener. Dis., 39, 109

Hare, M. J., Dunlop, E. M. C., and Taylor-Robinson, D. (1969): Ibid., 45, 282

Willcox, R. R., JefFeriss, F. J. G., and Naughten, E. M. (1966) Ibid., 42, 167.

\section{La recherche des contacts dans la gonococcie}

\section{SOMMAIRE}

On décrit une méthode intensifiée de recherche des contacts chez des hommes atteints de gonococcie.
119 hommes interrogés d'abord par le clinicien et ensuite par l'assistant social-au besoin plusieurs foisdésignèrent 145 partenaires récents. 40 pour cent des 117 sources d'infection citées et 82 pour cent des 28 contacts secondairement désignés furent retrouvés et examinés. Le taux total du succès des recherches fut de 48 pour cent. A partir des réponses des malades antillais, la découverte des contacts constituant un réservoir d'infection fut moindre que pour un nombre comparable d'hommes nés au Royaume Uni. Les résultats de cette méthode sont comrarés avec ceux obtenus par les simples fiches de désignation des contacts utilisées dans une étude similaire, publiée en 1963. La méthode actuelle est considérablement plus efficace dans la recherche des contacts qui servent de réservoir à l'infection. 